\title{
Nos trilhos do Museu de Artes e Ofícios: Exposição e público em Belo Horizonte/MG
}

\author{
On the tracks of the Museum of Arts and Crafts: \\ Exhibition and audience in Belo Horizonte/MG
}

Cláudia Eliane Parreiras Marques Martinez*

\section{RESUMO}

O objetivo desse artigo é apresentar os resultados preliminares de uma pesquisa realizada com aproximadamente quinhentos usuários do Metrô de Belo Horizonte (MG), em particular na plataforma de embarque da Estação Central. Uma das justificativas, apresentadas pelo museólogo Pierre-Yves Catel e pela equipe que participou da montagem e da organização do Museu de Artes e Ofícios (MAO), para a ocupação do prédio da Estação Central e sua ressignificação, transformando-o em uma instituição museal - voltada para a história/memória do trabalho pré-industrial e do trabalhador - foi a de que, naquela localização, poder-se-ia contar com "um público potencial de um milhão de visitantes por ano chegando pelo metrô". Nesse sentido, a pesquisa procura entender, sobretudo, a relação que se estabelece, na atualidade, entre o usuário do metrô e o Museu. No entanto, antes de revelar os dados dessa investigação, fez-se necessário analisar alguns aspectos que envolvem a história do MAO e, também, alguns pontos da exposição de longa duração apresentada ao público desde a inauguração da mencionada instituição, em 2006.

Palavras-chave: Museu de Artes e Oficios. Público. Usuário da Estação do Metrô. Exposição. Memória.

\section{ABSTRACT}

${ }^{1}$ Este trabalho faz parte da pesquisa de pós-doutorado realizada na Universidade Federal de Minas Gerais, no período de fevereiro de 2013 a julho de 2014, sob a supervisão do Prof. Dr. José Newton Coelho Meneses. O projeto intitulado - Patrimônio cultural e memória: mediações e intersecções entre dois museus brasileiros: Museu de Artes e Ofícios/MG e o Museu Histórico de Londrina/PR - consiste em estudar comparativamente esses dois museus brasileiros. As mediações foram pensadas em função da própria história das instituições e do processo de musealização das antigas estações ferroviárias de Belo Horizonte e de Londrina, que constituem hoje os referidos museus.

* Doutora em História Econômica pela Universidade de São Paulo (USP). Professora do Departamento de História e do Programa de Pós-graduação em História Social. Centro de Letras e Ciências Humanas - UEL Universidade Estadual de Londrina. Rodovia Celso Garcia Cid / PR, 445 km 380 / Câmpus Universitário. Londrina - PR. E-mail: cepmarques@uol.com.br 
The aim of this paper is to present the preliminary results of a survey of about five hundred subway users of Belo Horizonte (MG), particularly in the boarding platform of the Central Station. One of the reasons offered by museologist Pierre-Yves Catel and by the staff who took part in the assembly and organization of the Museum of Arts and Crafts (Museu de Artes e Ofícios -MAO), for the occupation of the building of the Central Station and its reinterpretation, which turned it into a museum institution dedicated to the history/memory of work and the workers -was that, at that place, it would be possible to find "a potential audience of one million visitors a year coming by underground". In this sense, the research seeks to understand, especially, the relationship that is established, at present, between the subway user and the Museum. However, before disclosing the data of this investigation, it was necessary to analyze some aspects concerning the history of MAO and also some aspects of the long-term exhibition presented to the audience since the inauguration of the mentioned institution, in 2006.

Keyword: Museum of Arts and Crafts. Audience. Subway user. Exhibition. Memory.

\section{Introdução}

Dos Gabinetes de Curiosidade ${ }^{2}$ ao século XXI, os museus percorreram um longo caminho, adotando diferentes concepções, não só de seus acervos e coleções, mas, principalmente, no que tange à tipologia das exposições. Não se pretende fazer uma análise da origem dessas instituições na Europa e, em particular, na América Latina, mas é importante destacar que, no Brasil ${ }^{3}$, a formação dos museus no século XIX também esteve intrinsecamente relacionada à afirmação e à consolidação da nação recém-criada, como denota uma historiografia especializada no assunto. ${ }^{4}$ No entanto, em razão da inexistência de uma tradição clássica, a questão da identidade nacional adquiriu aqui nuances diferenciadas, que se refletiram na composição dos acervos e no uso dessas coleções para a construção e a afirmação do poder político e do Estado nacional. (BREFE, 2005).

No século XX, nota-se um movimento concomitante estabelecido entre o avanço da prática museológica no Brasil (com a criação de centenas de museus no citado período) e o

\footnotetext{
${ }^{2}$ Os Gabinetes de Curiosidade na Europa, dos séculos XVI e XVII, tinham uma preocupação excessiva com a memória e "revelam um caráter enciclopedista, uma tentativa de se ter ao alcance dos olhos, pelo menos, o que existia em lugares distantes e desconhecidos. [...] Antes de qualquer coisa, trata-se de juntar, de colecionar objetos que dão a ideia da existência de 'outros'. O ato de colecionar transfigura-se em compreensão de tudo o que há no mundo” (POSSAS, 2005, p. 151). Acerca desse assunto, ver o texto de Helga Cristina Gonçalves Possas listado ao final deste artigo.

${ }^{3}$ No artigo de Ulpiano Toledo Bezerra de Meneses intitulado Do teatro da memória ao laboratório da História: a exposição museológica e o conhecimento histórico (1994), é possível encontrar uma discussão sobre o papel do museu na contemporaneidade. Essa discussão parte de duas premissas: 1) Que possibilidade pode haver de participação do museu histórico, na produção do conhecimento histórico?; 2) Como, nessa perspectiva, funciona a exposição museológica?

${ }^{4}$ É possível identificar vários autores que se dedicaram a estudar a história dos museus, a questão nacional e a identidade no Brasil. Ver, principalmente, os trabalhos de: Ulpiano Toledo Bezerra de Meneses, Ana Cláudia Fonseca Brefe, Letícia Julião, Myriam Sepúlveda dos Santos e outros, listados ao final deste artigo.
} 
desenvolvimento de debates. Observa-se, a partir da década de 1980, uma ampla reformulação dos museus (em especial os de caráter histórico), agora atentos não só para o diálogo com as novas correntes historiográficas, mas também preocupados em se aproximar de um público mais amplo. O Museu Histórico Nacional é um bom exemplo desse fenômeno museal contemporâneo. A instituição passou por uma reestruturação de sua expografia, antes voltada quase que exclusivamente para a celebração de uma memória nacional, alicerçada na exaltação de políticos, heróis do período imperial e membros da elite nacional. Até os anos 1980, a expografia seria um museu-memória, segundo a classificação da pesquisadora Myriam Sepúlveda dos Santos. (SANTOS, 2006).

Seguindo tendência mundial, assistiu-se, no Brasil, a partir do final do século XX, à fragmentação das instituições. Passaram a abranger temas e objetos antes inimagináveis, como a língua portuguesa, a imigração, a moda, os ofícios mecânicos, a cultura afroamericana, a cultura pantaneira, a imagem, o som e o futebol - só para destacar alguns casos.

Tendo em vista esse cenário multifacetado, fragmentado e dinâmico assumido pelos museus, busca-se, neste artigo, analisar alguns aspectos acerca da história do Museu de Artes e Ofícios/MG (MAO) e a exposição de longa duração divulgada ao público desde sua inauguração, em 2006. Também é objetivo apresentar os resultados preliminares de uma pesquisa feita com os usuários do Metrô em Belo Horizonte, particularmente na plataforma de embarque da Estação Central. A percepção e a interação que os usuários do metrô (potenciais visitantes museu) estabelecem (ou não) com a instituição museal foram alguns pontos observados e estudados na pesquisa de campo.

Cabe aqui nessas palavras iniciais uma nota sobre a bibliografia selecionada como suporte teórico e metodológico. $\mathrm{O}$ "diálogo entre a história e a antropologia" estabeleceu-se ao longo do texto por meio da contribuição de Néstor Canclini (1994) e Daniel Miller (2013). O aporte da antropologia e seus métodos de análise também podem ser encontrados na pesquisa realizada dentro do Metrô de Belo Horizonte e no estudo relacional entre a instituição museal, o público e a exposição. Ao lado dos antropólogos, seguem historiadores de referência na área da museologia e da memória como, por exemplo, Ulpiano Toledo Bezerra de Meneses (1994) e Dominique Poulot (2009, 2013), só para mencionar alguns nomes.

Desde já se faz necessária uma advertência. O leitor não encontrará aqui uma discussão verticalizada dos métodos e abordagens diferenciados dos autores selecionados antropólogos e historiadores. Priorizou-se, sobretudo, alinhavar a pesquisa realizada dentro e fora do MAO com alguns conceitos, ideias e metodologia de ambos, como se poderá ver no decorrer do artigo. Entende-se que a contribuição profícua de outras áreas de conhecimento ao campo da História, em particular a Antropologia, consolida-se quando esse diálogo ocorre de forma fluida, sem desconsiderar as especificidades inerentes a cada uma delas. 
Como já mencionado, as análises expostas neste artigo fazem parte de uma pesquisa mais ampla desenvolvida na Universidade Federal de Minas Gerais (UFMG), no Museu de Artes e Ofícios e na Companhia Brasileira de Trens Urbanos (CBTU), em Belo Horizonte. Os resultados preliminares permitiram nuançar, questionar e compreender melhor a justificativa da ocupação e da transformação do edifício em estilo neoclássico - construído no começo do século XX, para abrigar a Estação Central de Belo Horizonte - em um museu voltado para a preservação da memória do trabalho e do trabalhador brasileiro.

As palavras de um de seus idealizadores, o museógrafo Pierre-Yves Catel, ${ }^{5}$ dão a dimensão da proposta:

\begin{abstract}
A primeira questão que nos colocamos foi sobre o porquê de fazer o Museu de Artes e Ofícios num lugar como esse, uma estação de metrô. E queríamos entender o pensamento de Angela Gutierrez, que nos havia proposto fazer o projeto. É verdade que aqueles prédios não são apropriados para a criação de um museu. Museologicamente, não é um espaço ideal, ele impõe diversos problemas, mas o que levou à decisão foi sua situação privilegiada no que diz respeito ao público: graças a sua localização, contamos com um público potencial de um milhão de visitantes por ano, chegando pelo metrô. (CATEL, 2004 apud POULOT, 2013). Grifos nossos.
\end{abstract}

Diante disso, um conjunto de problemáticas comuns e complementares orientou o trabalho desenvolvido nestes dois espaços - o museu e o metrô. É possível fazer uma leitura da exposição relacionando-a com a escrita da História? Em caso afirmativo, como é possível identificar na expografia os vários discursos e linguagens presentes na História do final do século XX e no início do XXI? É pertinente pensar o museu, espaço por excelência de objetos históricos e artísticos, como uma plataforma de observação, marcada por forte visualidade? Qual a relação entre acervo museológico e a visualidade concebida por meio das exposições de longa duração ou por aquelas de caráter temporário? Qual o papel, ou melhor, quais as mensagens político-culturais - se é que existe alguma - por trás dos acervos e das imagens produzidas? Partindo do pressuposto de que existe uma identificação da sociedade com esses espaços, como essa relação se dá concretamente? Ou, ainda, como a sociedade em geral percebe e utiliza as representações criadas pelos acervos e exposições? Como as representações da antiga estação ferroviária, hoje espaço musealizado, atuam, interferem e dialogam com os discursos produzidos sobre a cidade de Belo Horizonte? Se a gestão do museu está diretamente relacionada ao bem cultural, questiona-se, por fim, como se dá a relação entre patrimônio, equipamento cultural e seu entorno (comércio, transeuntes, vizinhos, usuários do metrô e a própria cidade de Belo Horizonte).

\footnotetext{
${ }^{5}$ Segundo Dominique Poulot (2013), Pierre Catel foi discípulo de G.-H Rivière nas décadas de 1960/70. Deixou a instituição para montar uma empresa de museografia que empreendeu intervenções em mais de quarenta museus em todo o mundo. É possível ver seu trabalho em terras brasileiras: no Rio de Janeiro, com o projeto museográfico da Casa França-Brasil; em Ouro Preto, mediante a reforma do Museu da Inconfidência e, como já mencionado, em Belo Horizonte, com o Museu de Artes e Ofícios.
} 
Dentro desse rol de questões levantadas no projeto original estabelecemos aqui um recorte de ordem metodológica. Teremos como preocupação central a relação que se estabelece entre o público que circula pela Estação Central, o espaço museal e a exposição que ora se apresenta ao público. Para tal empreendimento, tornou-se preponderante apresentar ao leitor, mesmo que preliminarmente, alguns aspectos da história que envolve a edificação, a criação e a gestão do Museu, para, finalmente, apresentar os resultados da pesquisa empreendida na plataforma da Estação Central do Metrô, em Belo Horizonte.

\section{Três momentos de forte imbricação cultural: a Cidade, a}

\section{Estação, o Museu}

O fato de o edifício que acolhe hoje o MAO ter sido construído, inicialmente, para abrigar a Estação Central, em Belo Horizonte, é um ponto importante e não pode ser negligenciado. Também não se deve esquecer que a cidade, inaugurada em 1897, foi concebida e planejada por intermédio de propostas políticas e geográficas específicas. $\mathrm{O}$ Museu Histórico Abílio Barreto - considerado uma instituição de preservação da memória da cidade - constitui um espaço de excelência para o entendimento da ocupação, da fundação e da transformação da urbe, bem como das ideias de seus fundadores, arquitetos e políticos regionais, que atuaram, debateram e contracenaram entre si naquele momento. ${ }^{6}$

Do mesmo modo, o MAO também foi gestado conforme critérios específicos, projetados e pensados por um grupo de pesquisadores e profissionais de diversas áreas de conhecimento, como arquitetos, historiadores, museólogos, museógrafos, sociólogos etc. ${ }^{7}$ Segundo o catálogo do Museu, "o marco fundador do MAO é o dia 12 de dezembro de 2001, quando foi assinado o contrato de comodato entre o Instituto Cultural Flávio Gutierrez e a Companhia Brasileira de Trens Urbanos, para a ocupação do espaço físico". 8

${ }^{6}$ Segundo o site do Museu Histórico Abílio Barreto, este foi "criado por meio do decreto municipal 91, de 26 de maio de 1941" e "tem por função promover o recolhimento, a preservação, a pesquisa e a divulgação do acervo histórico relativo a Belo Horizonte; sua finalidade é tornar público o acesso aos bens culturais preservados, fomentando, dessa maneira, a participação dos cidadãos na construção da memória e do conhecimento sobre a cidade." Contribui, assim, para a formação de uma consciência crítica sobre a relação passado-presente e para o exercício da cidadania. Maiores informações no site: http://www.amigosdomhab.com.br/.

${ }^{7}$ Antes da inauguração do Museu, Angela Gutierrez, idealizadora do projeto, empreendeu uma série de encontros, reunindo especialistas de várias áreas do conhecimento, como a museologia, a história, a sociologia, a arquitetura. O resultado desses encontros científicos para debater as propostas e possibilidades da execução do projeto museológico resultou na publicação do livro Seminários de Capacitação Museológica, listado ao final deste artigo e tratado aqui como documento histórico.

${ }^{8}$ Criado em 1998, o ICFG é uma entidade do terceiro setor, sem fins lucrativos, e que atua especialmente em projetos museológicos e museográficos, tais como o Museu do Oratório, em Ouro Preto; o 
O que gostaríamos de sublinhar é que cada um deles - a cidade e o museu -, a seu modo e a seu tempo, atuaram na construção de uma história e de uma identidade singular. O MAO nasce com a intenção de preservar e divulgar uma memória ligada ao universo dos ofícios e das artes mecânicas do passado nacional, bem como do trabalhador brasileiro. A exposição, que ocupa os dois prédios (conhecidos como o lado A e o lado B), é composta por uma coleção de forte peso cultural, tanto em termos quantitativos quanto qualitativos, e dificilmente deixa de fascinar o público visitante.

Além de uma coleção histórica e complexa nota-se que a edificação também constitui um veículo imagético de grande impacto cultural na cidade (figura 1). De antiga estação ferroviária transformou-se em espaço museal e tem procurado, desde então, aproximar e assimilar as várias identidades e memórias da cidade de Belo Horizonte, bem como mesclarse com elas. Tendo consciência desse fato, os materiais produzidos e divulgados pelo museu estão carregados de símbolos, alegorias e marcos históricos que procuram explorar a arquitetura do prédio, relacionando-a não só com a história da cidade, mas também com o estado de Minas Gerais e com o Brasil.

Do mesmo modo, tanto a CBTU quanto a Ferrovia Central do Brasil, que passa ao lado do Museu, são referências regionais e nacionais de grande importância para a história do transporte de mercadorias, do fluxo e da circulação de pessoas, não só da cidade de Belo Horizonte, mas também de diferentes partes do Brasil, como pudemos constatar na pesquisa realizada no período de fevereiro de 2013 a julho de 2014.

Vejamos alguns aspectos da história da Estação Central do antigo Curral Del Rey, implantada em 1895, dois anos antes da inauguração da nova capital mineira. O primeiro prédio foi demolido poucos anos depois da construção, dando início, nas primeiras décadas do século XX, ao edifício atual, em estilo "eclético" e com influência neoclássica, como se pode observar tanto na figura 1 quanto em sua representação no prato ${ }^{9}$ que hoje faz parte do acervo de outra instituição, o Museu Histórico Abílio Barreto/MG, (figura 2). Depois de ampla adaptação e restauração, concluída em 2005, a antiga estação ferroviária de Belo Horizonte passou a abrigar o maior conjunto de objetos e artefatos relacionados ao tema das artes e ofícios no Brasil. ${ }^{10}$

Museu de Artes e Ofícios em Belo Horizonte e, mais recentemente, o Museu de Sant'Anas, inaugurado no dia 19 de setembro deste ano, na cidade de Tiradentes.

${ }^{9}$ Segundo informações do Álbum do MHAB, "a peça integra um conjunto de outros cinco pratos confeccionados na Holanda, por Petrus Regout e Comp. Masstrich, em 1917, a pedido de José Ribeiro, proprietário da Casa Crystal. Foi adquirida pelo Museu Histórico Abílio Barrreto em novembro de 1944, diretamente desse estabelecimento comercial". Ver Álbum do MHAB, que pode ser adquirido na loja desse museu.

${ }^{10}$ Maiores informações no site do Museu de Arte e Ofícios: http://www.mao.org.br/. 


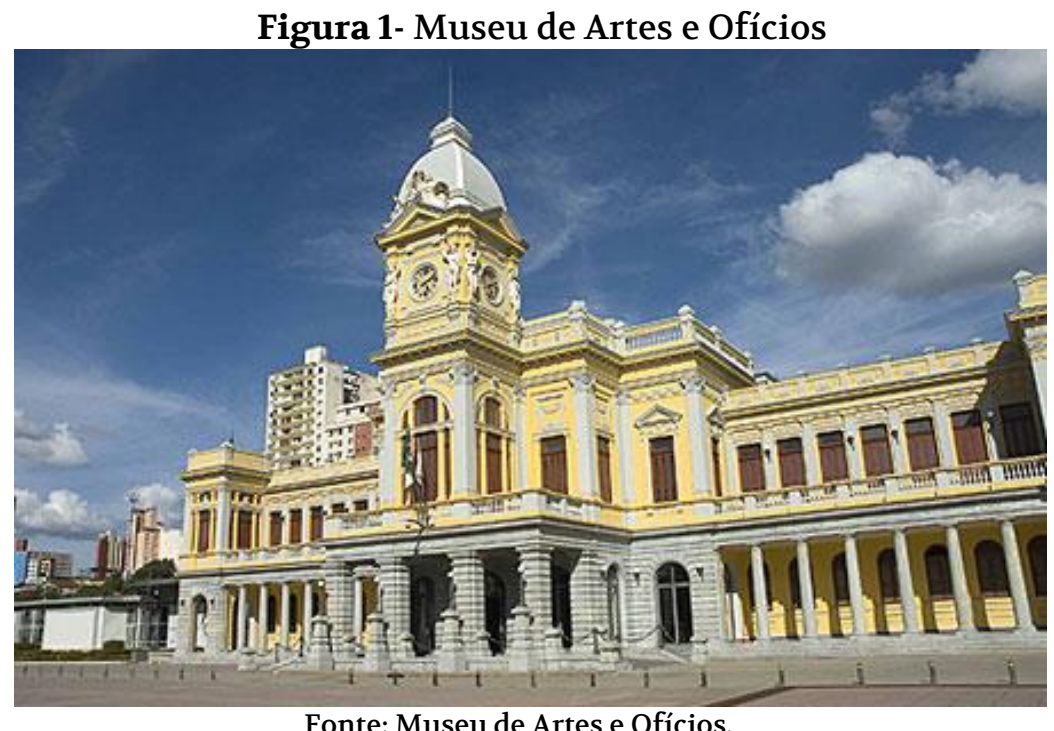

Fonte: Museu de Artes e Ofícios.

O prédio ferroviário, ao se transformar em museu, permite refletir sobre o papel desempenhado no passado e na atualidade. A partir da segunda metade do século $\mathrm{XX}$, as estações ferroviárias brasileiras gradativamente perderam a função de transporte público e de meio de escoamento da produção agrícola. Com a popularização do automóvel e o concomitante desinteresse político-econômico sofrido pelas ferrovias, os antigos edifícios constituem agora representações de um passado. Suas imagens são encontradas e, principalmente, comercializadas, por meio de cartões postais, álbuns de figurinhas para crianças e souvenirs, como denota a imagem de uma xícara com o logotipo do museu, vendida na loja da instituição e selecionada, aqui, entre muitos outros exemplos (figura 3). Desde peças funcionais a artefatos decorativos e simbólicos - pratos, canecas, chaveiros, camisetas, blocos de anotações, cartões postais, cadernos, canetas, bolsas, sacolas etc... -, as mais variadas peças podem ser adquiridas no Museu.

O prato decorativo que retrata o prédio da Estação Central (hoje, Museu de Artes e Ofícios/MG), faz parte do acervo do Museu Histórico Abílio Barreto/MG e constitui um caso inusitado. Segundo as informações extraídas do "Álbum do MHAB",1 a peça integra um conjunto de outros cinco pratos fabricados, na Holanda, por Petrus Regout e Comp. Masstrich, em 1917, a pedido de José Ribeiro, proprietário da Casa Crystal. A louça foi adquirida pelo Museu Histórico Abílio Barreto em novembro de 1944, diretamente desse estabelecimento comercial.

\footnotetext{
${ }^{11}$ Esse trabalho se dirige, essencialmente, ao público jovem. Em visita ao MHAB, em 2008, pudemos presenciar um grupo de adolescentes que entusiasticamente comprava o material na loja do Museu e, de imediato,

iniciava o trabalho de identificação das figurinhas e legendas, fazendo comentários a respeito da história e do tema do álbum sobre a criação e transferência da capital mineira de Ouro Preto para Belo Horizonte, em 1897.
} 
O curioso dessa história é que, ao atravessar o oceano - da Holanda para o Brasil -, o objeto decorativo acabou transformando-se em acervo de outro museu que não o representado na peça. Além de ser retratada numa das figurinhas do álbum destinado a "contar", para um público jovem, a história da ocupação e da inauguração da nova capital mineira, no final do século XIX, a peça integrou a exposição do Museu Histórico Abílio Barreto alguns anos atrás.

Diferentemente do prato de origem holandesa - objeto raro e singular do acervo MHAB -, os diversos itens (figura 3) disponíveis na loja do Museu de Artes e Ofícios materializam, de outra forma, a imagem do museu e os símbolos que o acompanham. O visitante, ao adquiri-los, leva consigo não só souvenirs, mas o que eles simbolizam: o ato de lembrar, que eterniza aquele momento, ou situações carregadas de afetividade vivenciadas com amigos e familiares.

Figura 2- Prato decorativo com imagem da

Estação Central, em Belo Horizonte, 1917

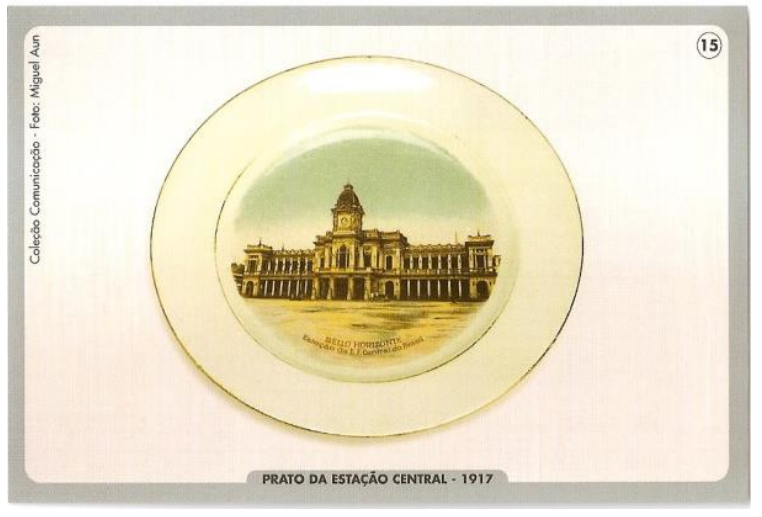

Fonte: Álbum de Figurinhas do MHAB, 2003.
Figura 3- Caneca decorativa com o logotipo do MAO, 2014

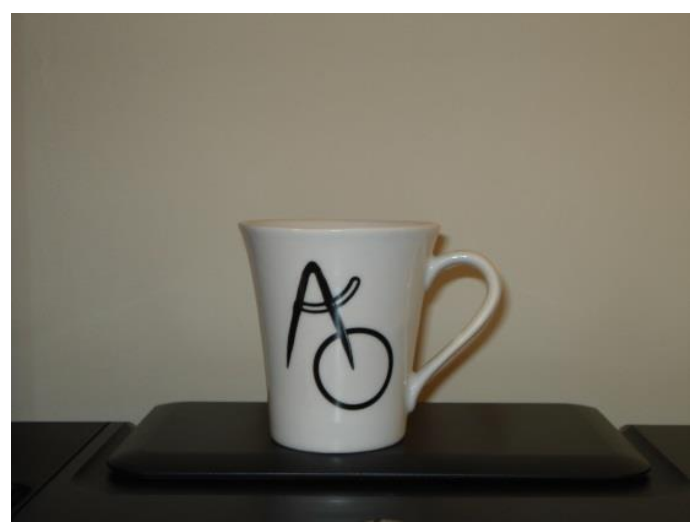

Fotografia: Cláudia Martinez, 2014.

O Museu de Artes e Ofícios trouxe ao público uma coleção de aproximadamente 2.500 peças, datadas dos séculos XVIII ao XX. A instituição possui uma Reserva Técnica de pequeno porte, porém equipada e climatizada segundo as normas estabelecidas pela Nova Museologia. Em visita realizada em agosto de 2013, pudemos observar que as peças estavam devidamente guardadas em estantes deslizantes e que alguns objetos encontravam-se em processo de restauro. A museóloga que nos acompanhou na visita declarou que praticamente toda a coleção pertencente ao acervo do Museu estava em exposição. Isso, em si, não seria uma questão a ser pensada pela instituição? Por que tudo tem que estar em evidência em um só tempo e lugar? Ao evidenciar toda a coleção - e ela é imensa - o Museu não estaria sobrecarregando os corredores e salas, que, como o próprio Pierre Catel salientou, não são os de um edifício próprio para a instalação museológica, daí as adaptações necessárias e realizadas? 
Por outro lado, o conjunto de objetos ali expostos permite compor um quadro dinâmico da história e das relações sociais do mundo do trabalho. $O$ projeto do arquiteto e museógrafo francês teve como objetivo ocupar os dois prédios "através de um túnel e transformou as áreas externas próximas às plataformas de embarque e desembarque em galerias expositivas, criando uma surpreendente estação-Museu. A estação de metrô e a estação ferroviária continuariam operando normalmente". (MUSEU DE ARTES E OFÍCIOS, 2013).

A instituição, que abrange um espaço de $9.200 \mathrm{~m}^{2}$, possui também um jardim-Museu com peças de grande porte (como um engenho de cana, um moinho etc...), restaurante/cafeteria, espaço para eventos científicos e áreas de convivência, além de uma loja, como já referido aqui, com produtos que trazem (sempre) a imagem do museu e/ou de seu acervo. $O$ diferencial é que a instituição passou a conviver - e essa foi a justificativa principal para ocupar aquele espaço - simultaneamente com a estação de metrô, que atendeu, só no mês de junho deste ano, cerca de 524.510 mil usuários, segundo os dados coletados na CBTU..$^{12}$ Vejamos, agora, como se dá a relação estabelecida entre o Museu de Artes e Ofícios e a exposição de longa duração.

\section{A exposição e o Museu}

Ao visitar a exposição, o público encontra uma coleção de caráter histórico e artesanal. É a partir dessa plataforma de observação que se entra em contato com os objetos ligados ao mundo do trabalho pré-industrial. Segundo Antonio Tomasi, o espaço museal é:

[...] o lugar de encontro do trabalhador consigo mesmo, com sua história, com seu tempo - passado, presente e futuro. É um projeto em permanente construção. Ele se realiza no olhar do visitante, que dá sentido aos objetos (MUSEU DE ARTES E OFÍCIOS, 2013, p. 7). Grifos nossos.

Para os idealizadores do Museu, as centenas de artefatos permitem uma associação direta com a memória e tudo o que ela implica em termos de sentimentos, lembranças e esquecimentos. Os objetos estão dispostos/expostos; classificados segundo seus ofícios e divididos em oficinas e salas, de modo que o visitante, ao percorrer os longos corredores, pode (re)conhecer as profissões do passado, muitas delas identificadas com sua própria

\footnotetext{
${ }^{12}$ Pudemos realizar, no primeiro semestre de 2014, uma pesquisa na Companhia Brasileira de Trens Urbanos (CBTU). A equipe técnica colocou a nossa disposição os dados quantitativos de toda a movimentação do metrô relativa ao período de janeiro de 2013 a julho de 2014. Além disso, foram-nos gentilmente cedidos o material da ação educativa e demais materiais didáticos e pedagógicos produzidos pela empresa.
} 
história ou a de seus antepassados. ${ }^{13}$ Dos depoimentos deixados no Livro de Visitante os casos do Sr. Josué e de Dona Nilce atestam, a exemplos de tantos outros, a força simbólica que os objetos suscitam no público em geral:

Achei espetacular; é um museu muito importante pela quantidade e perfeição dos objetos antigos. Trabalhei com alguns deles na agricultura.

Josué Guido de Oliveira nossos).

Natural de Ribeirão Vermelho/Minas Gerais (12 abr. 2013, grifos

Um espaço de extrema importância. Fiquei deslumbrada com tudo que vi. Foi um verdadeiro passeio pelo passado. Lembrei-me de muitos objetos das casas de minha infância, avós e bisavós etc.

Nilce Maria P. O. Machado (DN) 19 abr. 1960.

Natural de Cássia/Minas Gerais (12 abr. 2013, grifos nossos).

O leitor pode estar-se perguntando: "Qual o problema que esse tipo de expografia e/ou proposta museológica apresenta na prática e na teoria?" Ou, ainda, se os sentimentos despertados nos visitantes - que, ao (re)verem os objetos, são tomados pelas lembranças individuais ou coletivas - não poderiam ser interpretados como algo positivo e desejável no que se refere a qualquer museu? Em princípio, a resposta certamente seria: "Sim!" Mas o fato para o qual estamos tentando chamar a atenção é "o outro lado da moeda". Dito de outra forma: o que está por trás das cortinas; os bastidores de (qualquer) exposição. O que parece naturalizado para o visitante, na verdade, tem um sentido maior. Em geral, foi pensado e orquestrado por um grupo de pessoas que, como é inerente a todo projeto, fizeram escolhas e recortes.

Antes de expor mais detidamente essa ideia, não podemos deixar de lembrar, novamente, a classificação proposta por Myriam Sepúlveda dos Santos, quando ela se refere aos dois tipos de museus: o museu-memória e o museu-narrativa (SANTOS, 2006). Seguindo a tipologia da autora, podemos dizer que a categoria "memória" presente no MAO suplanta, ou dificulta estabelecer uma narrativa histórica. A própria exposição - fruto de uma coleção adquirida durante décadas pela família Gutierrez - e a criação da instituição para abrigar esses objetos sinalizam o lugar de destaque que tais objetos adquiriram naquele espaço. A temporalidade construída na/pela expografia é - como nos museus-memória - descontínua e pontual; os artefatos acabam assumindo a função de meras alusões ou amostras do passado, e não representações possíveis de uma realidade histórica. Parece que essa foi a opção do Museu, ao explicar como lidou com a questão da cronologia, por exemplo:

${ }^{13}$ A exposição está distribuída nos dois prédios, segundo os Ofícios: Transporte, Ambulantes, Comércio, Mineração, Fogo, Madeira, Cerâmica, Lapidação e da Ourivesaria, Couro, Conservação e Transformação dos Alimentos, Fio e Tecido, além da sala denominada "Proteção do Viajante" e o "Jardim das Energias". 
Sem se fixar numa apresentação cronológica, foram identificadas iconografias que registram a trajetória dos ofícios até o século XXI. O material selecionado contextualiza os objetos sem substituí-los e serve de apoio à compreensão geral de sua utilização, contribuindo também para que o visitante apreenda toda a dimensão imaterial do acervo (MUSEU DE ARTES E OFÍCIOS, p.9, 2013). Grifos nossos.

A questão que se coloca é que, em meio a tantos objetos e artefatos, o sujeito histórico acabou sendo ofuscado ou, até mesmo, esquecido. Vejamos essa questão no campo historiográfico. Nesse caso, observam-se, ao longo do século XX, transformações no que tange à narrativa histórica. De uma abordagem que priorizava os heróis, os "grandes homens" e os dirigentes políticos, a partir, principalmente, da Nova História, a vida daqueles indivíduos pertencentes às camadas mais baixas da sociedade e/ou homens e mulheres anônimos passaram a compor temas e objetos passíveis de investigação, como qualquer outro sujeito histórico ${ }^{14}$.

No caso dos museus, essa abordagem mais tradicional da história foi, durante muito tempo, reproduzida em suas concepções; isso, claro, repercutiu diretamente na expografia dessas instituições. No caso brasileiro, três exemplos bastam para justificar o que acabamos de dizer.

Na cidade de Ouro Preto, em Minas Gerais, o Museu da Inconfidência (MI), inaugurado na década de 1940, foi pensado exatamente para enaltecer e consolidar o mito dos inconfidentes como heróis, não só dos mineiros, mas de toda a "nação brasileira". Mesmo com a reestruturação musegráfica, a cargo de Pierre Catel, em 2006, as questões ideológicas e o "mito" criado em torno dos inconfidentes mantiveram-se na museografia, como mostra o trabalho de Rafael da Silva Alves (2013).

Caso semelhante pode ser observado no Museu Paulista (MP). A partir da gestão de Afonso d'Escragnolle Taunay (1917-1945), empreendeu-se com afinco um processo de separação das coleções de ciências naturais daquelas de história, que passaram, então, a constituir a "alma do museu" (BREFE, 2005, p. 24-25). Segundo Brefe, o objetivo de Taunay era "contar a história da constituição da nação brasileira do ponto de vista de São Paulo, isto é, como resultado do esforço paulista desde os primórdios da colonização". O Museu tornase, assim, o palco, o grande cenário "em que essa história vai tomar corpo e materialidade", tendo como foco os bandeirantes e aqueles que se destacaram na política de São Paulo dos séculos passados (BREFE, 2005, p. 24-25).

O Museu Histórico de Londrina/PR constitui um caso emblemático, porque, em suma, revela uma faceta muito comum presente nos museus regionais do Brasil. Criado nos anos

${ }^{14} \mathrm{O}$ caso de Menocchio - um simples moleiro do século XVI perseguido pela Inquisição e cuja vida foi descortinada pelo historiador italiano Carlo Ginzburg (1987), que buscou entender, entre muitas questões, a cultura popular e erudita na época - constitui um bom exemplo. 
1970, tem como um dos pilares a história dos seus "primeiros" habitantes. Londrina é uma cidade que completa agora 80 anos. Inaugurada no Norte do Paraná, em 1934, a cidade do sul do Brasil, diferentemente de Belo Horizonte, foi planejada para ser polo aglutinador da nova economia (essencialmente o cultivo cafeeiro) que marcou a Era Vargas e os decênios seguintes, atraindo centenas de imigrantes, os quais pertenciam a diversas etnias (ADUM, 2008).

O que interessa destacar aqui é que os objetos do cotidiano e de trabalho originados nessas primeiras décadas de ocupação e desenvolvimento da urbe e de seus arredores foram doados e reunidos, contribuindo para a formação de um acervo inicial e para a criação do Museu. A instituição, inaugurada em 1970, tornou-se órgão suplementar da Universidade Estadual de Londrina (UEL) quatro anos depois. Somente em 1986 é que o acervo existente transfere-se para o prédio da antiga Estação Ferroviária, tornando-se não só um Museu Histórico com sede própria, mas uma referência cultural para a cidade e a região norte do estado do Paraná.

De forma singular e, ao mesmo tempo, análoga, no que concerne aos dois outros museus citados, o MHL também teve como pilar de seu discurso a história mítica dos "primeiros", nesse caso, homens em geral ligados à Companhia de Terras que chegaram à região e, por isso, denominados "pioneiros". Dos três casos citados, podemos dizer, buscando uma síntese, que, com forte imbricação ideológica, os bandeirantes paulistas, os inconfidentes mineiros e os pioneiros de Londrina alimentaram, durante décadas, os "mitos fundadores", ofuscando e desconsiderando outros atores sociais que da mesma forma participaram do processo histórico (ADUM, 2008, LEME, 2013).

Se a personificação é problemática porque traz ideologias subjacentes; dogmas, versões e "verdades" forjadas para enaltecer determinados indivíduos ou classes sociais, como se pôde constatar nos três casos citados, o contrário também parece implicar problemas que demandam discussão. Questões de várias ordens e com repercussões categóricas na forma de representação social, no fazer histórico e, ainda, nos pressupostos museológicos. Ou seja, o anonimato completo acaba retirando do objeto as inferências e as imbricações com outras esferas de sua existência, a humana inclusive. Afinal, por trás de todo objeto há um ser humano. Se levarmos essa questão ao limite, as ideias do antropólogo Daniel Miller são modelares. "Os troços, as coisas nos fazem na mesma medida em que são feitos por nós" (MILLER, 2013, p. 31).

Vejamos a fala da diretora Angela Gutierrez, ao discorrer sobre a questão dos "trabalhadores anônimos" no Catálogo do Museu: 
A história do Brasil pode ser contada a partir do legado de milhares de trabalhadores anônimos, homens e mulheres que deixaram suas marcas em múltiplas atividades, nos campos e nas cidades, ao longo de vários ciclos da vida brasileira. (MUSEU DE ARTES E OFÍCIOS, 2013, p.3).

A ideia apresentada pela gestora é coerente e condizente com a proposta da instituição. No entanto, seria mais pertinente se fosse possível resgatar a "origem" daquelas peças, os lugares de onde elas vieram, a relação que tinham com seus antigos proprietários etc. Um trabalho semelhante, e do ponto de vista museológico imprescindível, foi realizado pelo Museu Paulista, com o acervo que era doado pelos moradores da cidade paulistana. Além de todas as informações do doador, eram catalogados a história do objeto e a relação que aquela peça tinha com seus antigos donos - enfim, historicizavam-se as práticas estabelecidas entre o "antigo dono" e o artefato. Segundo as pesquisadoras Lima e Carvalho (2005, p. 87-87):

Os museus e arquivos, ao abrigar artefatos de toda ordem, tornaram-se poderosos colecionadores. Colecionismo institucional e privado compartilham procedimentos que orientam a produção de sentidos em torno da definição biográfica de seu titular. [...] $\mathrm{O}$ colecionismo é, por isso, uma plataforma estratégica quando se trata de entender aspectos da reprodução das relações sociais. Para tanto é preciso historicizar as práticas da curadoria que estão na origem de coleções privadas tornadas institucionais.

Claro que essa tarefa seria impossível para todo o acervo, não só o existente no MAO, mas o de quase todos os museus em geral. Mas o esforço para resgatar a história do artefato (com, pelo menos, parte do acervo) poderia, sim, enriquecer a discussão, a exposição. Mais que isso: poderia humanizar as centenas de peças que compõem a coleção.

Poder-se-ia, a partir do exposto, perguntar: "Como o MAO se relaciona, então, com a questão do sujeito histórico?" Para falar dos homens e mulheres o museu recorre, quase sempre, à tecnologia e aos recursos de multimídia. Se a coleção é significativa - e disso não há dúvidas -, temos consciência de que os documentos não falam por si mesmos (BLOCH, 2002). Mais que isso, não "é preciso apenas olhos para vê-los", como afirma Antonio Tomasi, em publicação aqui já citada (MUSEU DE ARTES E OFÍCIOS, 2013, p. 7). São necessários elementos e informações para interpretá-los, analisá-los e entendê-los, e não apenas despertar "sentimentos" que emanam de lembranças e memórias vividas e/ou contadas pelos antepassados - embora isso também seja relevante. 
Não se pode nunca perder de vista o fato de que o público está "vendo" uma exposição e/ou coleção que, em princípio, foi selecionada, escolhida e, por fim, recortada. Somente depois dessa "operação cirúrgica" é que os artefatos foram deslocados dos "velhos galpões", despidos de alguma impureza (como sujeira e imperfeições), para finalmente serem expostos à contemplação, ao deleite ou à simples observação. Meneses já tinha advertido a respeito dessa ideia, quando chamou a atenção para a necessidade de explicitar a natureza/concepção das exposições (MENESES, 1994). Em sua opinião, esse tipo de evento visual não deveria ser apenas uma "convenção" de ordem cronológica, tipológica ou classificatória, por exemplo. $\mathrm{O}$ autor segue indagando que toda mostra de objetos deveria estabelecer, por meio dos artefatos, uma "linguagem museológica" (MENESES, 1994, p. 30).

Nesse sentido, então, nós é que "falamos" pelos objetos de madeira, pedra, cerâmica etc... E, quando "pensamos" por e para eles, acabamos criando discursos e narrativas sujeitas a múltiplas interpretações e olhares. Enfim, são os pesquisadores que têm a responsabilidade de (re)construir e interpretar a história dos indivíduos e de não imputar aos documentos/objetos essa função. Nunca devemos esquecer que as peças (de couro, tecido, vidro etc...) são apenas instrumentos, veículos - base imprescindível para a construção da exposição -, mas não o narrador. Os artefatos dispostos na antiga plataforma do metrô, em alguns momentos, parecem cristalizados no passado; é como se bastasse observá-los para que a história se fizesse diante dos olhos...

A instituição procura, por meio de vídeos, dos quiosques e totens, (re)estabelecer a relação passado/presente, bem como a conexão entre o material (objeto) e o humano (sujeito histórico). No entanto, os recursos visuais, sonoros e todo o aparato tecnológico acabam tendo um papel ilustrativo e ornamental dentro da exposição. Conduz o visitante a um tempo idílico, no qual conflitos e tensões sociais não são problematizados e/ou questionados. Corre-se o risco do público sair da exposição com uma visão romântica do passado e do trabalho pré-industrial na América portuguesa e no Brasil.

Vejamos alguns exemplos. No salão da entrada do Museu - onde também se localizam o restaurante, a cafeteria e a loja - o visitante pode ter acesso a várias informações sobre a coleção, a exposição, a restauração do prédio, tudo isso, por meio dos recursos de multimídia. Em geral, o visitante se depara com o discurso daqueles que participaram direta, ou indiretamente, da concepção e da construção do museu.

Em um desses quiosques, localizado perto da entrada que dá acesso ao primeiro edifício, ao tocar na imagem de uma plaina ou de um avental de curtume, que aparece na tela, o visitante pode escutar:

Quem nunca teve, ao observar algum trabalhador, a impressão de não ser mais capaz de dizer onde termina o corpo e onde começa a 
matéria prima e a ferramenta. [...] Na longa relação entre este avental de curtume e a pessoa que o usou constantemente a vida inteira quem fez o que, quem moldou, foi moldado, o corpo moldou o objeto ou foi o contrário? (Depoimento de Angela Gutierrez, extraído do totem da entrada principal do MAO).

\section{O Museu e o público/usuário do Metrô}

Como se pôde observar no item anterior, a história da criação do MAO e sua exposição permitem nuançar conceitos que envolvem os museus, a memória e a identidade, mas foi por meio da pesquisa de campo que essas e outras questões puderam ser descortinadas. Durante o primeiro semestre de 2014, realizamos 461 entrevistas com os usuários do metrô, em Belo Horizonte. A elaboração das perguntas teve como diretriz principal o público que circula (diariamente ou esporadicamente) pela Estação Central e, por esse mesmo motivo, estabelece uma relação direta e simultânea com a Praça da Estação e o Museu.

Optou-se por formular dois núcleos de questões: o primeiro, de caráter socioeconômico, tais como: sexo, idade, profissão, escolaridade e frequência com que as pessoas utilizam o metrô. O segundo núcleo refere-se às informações que permitem entender a relação do espaço do metrô com o museu. Com relação a esses dados, destacam-se as seguintes indagações: 1) Você sabia que na Praça da Estação existe um museu - o Museu de Artes e Ofícios? 2) Se sim: você já teve a oportunidade de visitar o Museu? 3) O que você mais gostou nessa visita? 4) Se não: qual o motivo pelo qual ainda não visitou o Museu?

Para a execução da pesquisa dentro da plataforma do Metrô, foi necessária a autorização da CBTU, que permitiu realizar a atividade em dois períodos diurnos: matutino (das $9 \mathrm{~h}$ às $11 \mathrm{~h}$ ) e vespertino (das $16 \mathrm{~h}$ às $18 \mathrm{~h}$ ). Durante os meses de maio, junho e julho, frequentamos a estação nesses dois intervalos, aplicando os questionários e entrevistando os usuários ${ }^{15}$.

Os resultados apontaram que $58 \%$ dos usuários são constituídos por mulheres e que a média de idade gravitou em torno de 36 anos. A maioria de mulheres, encontrada em relação aos homens, embora não tão discrepante, pode estar relacionada aos horários em que os questionários foram aplicados, sempre no meio da manhã e no final da tarde. Se tivéssemos a oportunidade de aplicar esse mesmo questionário em outros horários (por exemplo, no período noturno), os resultados poderiam apresentar diferenças mais sensíveis.

\footnotetext{
${ }^{15}$ Para a realização do trabalho das entrevistas, foi possível contar com o precioso auxílio de Ludmila
} Machado, aluna do curso de graduação em História da Universidade Federal de Minas Gerais. 
Quanto ao uso do metrô, quase $58 \%$ dos entrevistados utilizam os trens diariamente e $42 \%$, esporadicamente (ou seja, de 1 a 3 vezes na semana). Como a linha férrea não atravessa nem abrange a maioria dos bairros, o cidadão precisa utilizar ônibus como meio de transporte, o que vem reforçar a necessidade da ampliação da rede metroviária em Belo Horizonte.

Sobre o nível de escolaridade, não obtivemos nenhuma informação de analfabetismo, ou seja, nenhum entrevistado declarou não saber ler e/ou escrever. Do total, $43 \%$ afirmaram ter ensino médio completo; $18 \%$, superior completo, e $10 \%$ estavam cursando alguma faculdade/universidade. Da população abordada, $12 \%$ não haviam concluído o ensino fundamental completo; isso quer dizer que alguns estavam em curso e outros abandonaram a escola. Os dados corroboram e revelam uma situação relativamente nova no País, ou seja, a amostra denota alterações positivas no nível de escolaridade em Minas Gerais, como aponta o gráfico 1.

Gráfico 1- Escolaridade dos usuários do Metrô

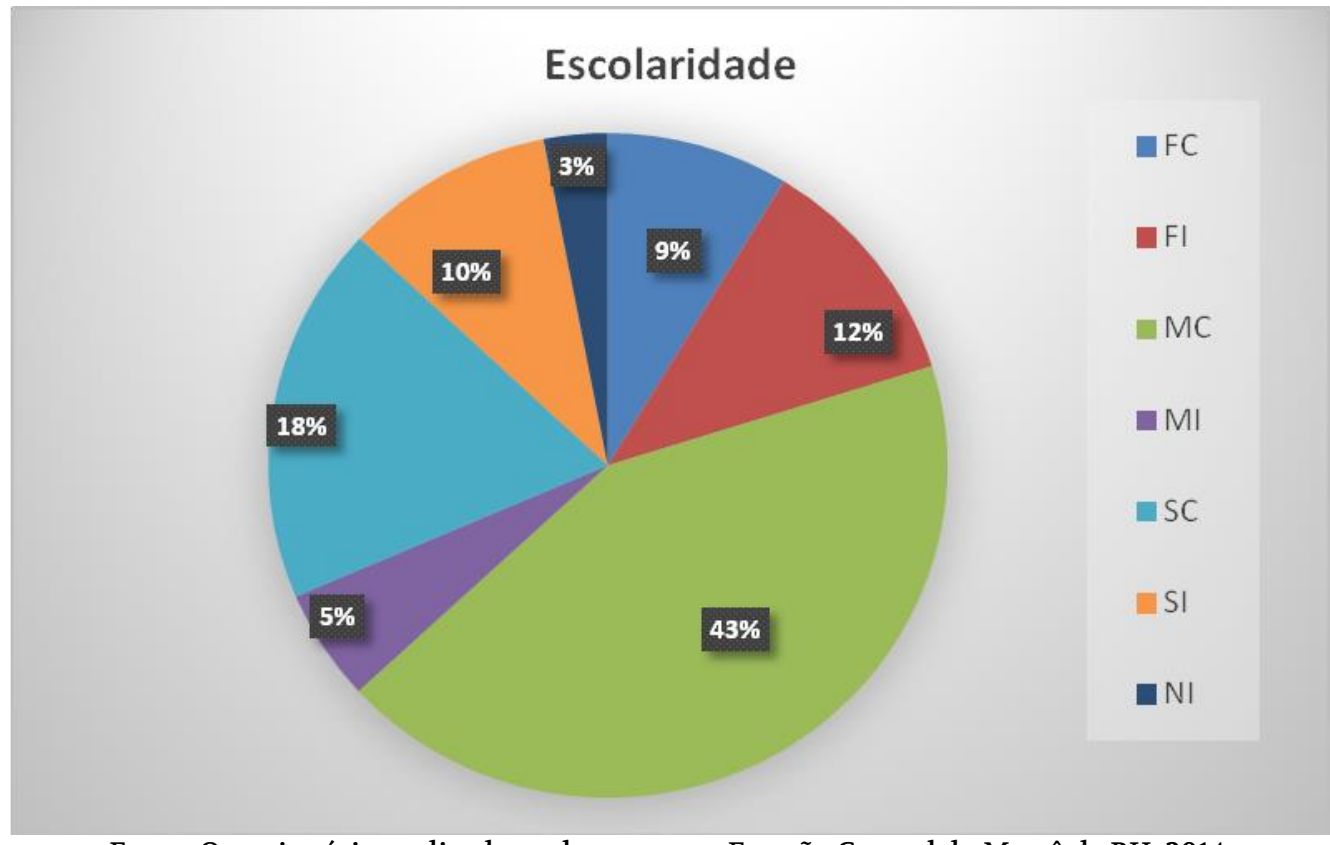

Fonte: Questionários aplicados pela autora na Estação Central do Metrô de BH, 2014.

Legenda FC significa Fundamental completo; FI - Fundamental incompleto; MC - Médio completo; MI Médio Incompleto; SC - Superior completo; SI - Superior incompleto; NI - Não informaram

A fim de analisar as ocupações, foi necessário, em decorrência da grande variedade tipológica, agrupá-las por setor. Para isso, foram utilizadas as informações postas à disposição pelo Ministério do Trabalho. ${ }^{16}$ Como se esperava, os chamados "serviços gerais"

${ }^{16}$ Ver a lista de todas as ocupações existentes no Brasil em www.mte.gov.br/. 
(domésticas, operários da construção civil, cozinheiros, diaristas etc.) constituíram a maioria das ocupações registradas: $54 \%$. Um número razoável de profissionais liberais (26\%), seguido por um pequeno percentual de estudantes $(8 \%)$ e aposentados $(1,7 \%)$, também foi encontrado na amostragem. Além disso, apenas 6 pessoas se declararam desempregadas.

Cabe aqui retomar a problemática central deste trabalho. $\mathrm{O}$ discurso que orientou a ocupação e a ressignificação do edifício da antiga Estação do Metrô em um museu foi exatamente o grande fluxo de trabalhadores que circula diariamente naquele espaço. Por esse motivo, esses homens e mulheres estariam em contato mais direto com o Museu, uma instituição que tem como acervo, coleção e exposição objetos relacionados ao mundo do trabalho e das atividades manuais e mecânicas do passado brasileiro. Ao perguntar aos usuários do metrô se eles sabiam da existência do Museu de Artes e Ofícios, 80\% disseram que "sim". No entanto, quando se perguntou se já tinham tido a oportunidade de visitá-lo, apenas $25 \%$ deram uma resposta afirmativa.

Gráfico 2- Ocupação por categoria dos usuários do Metrô

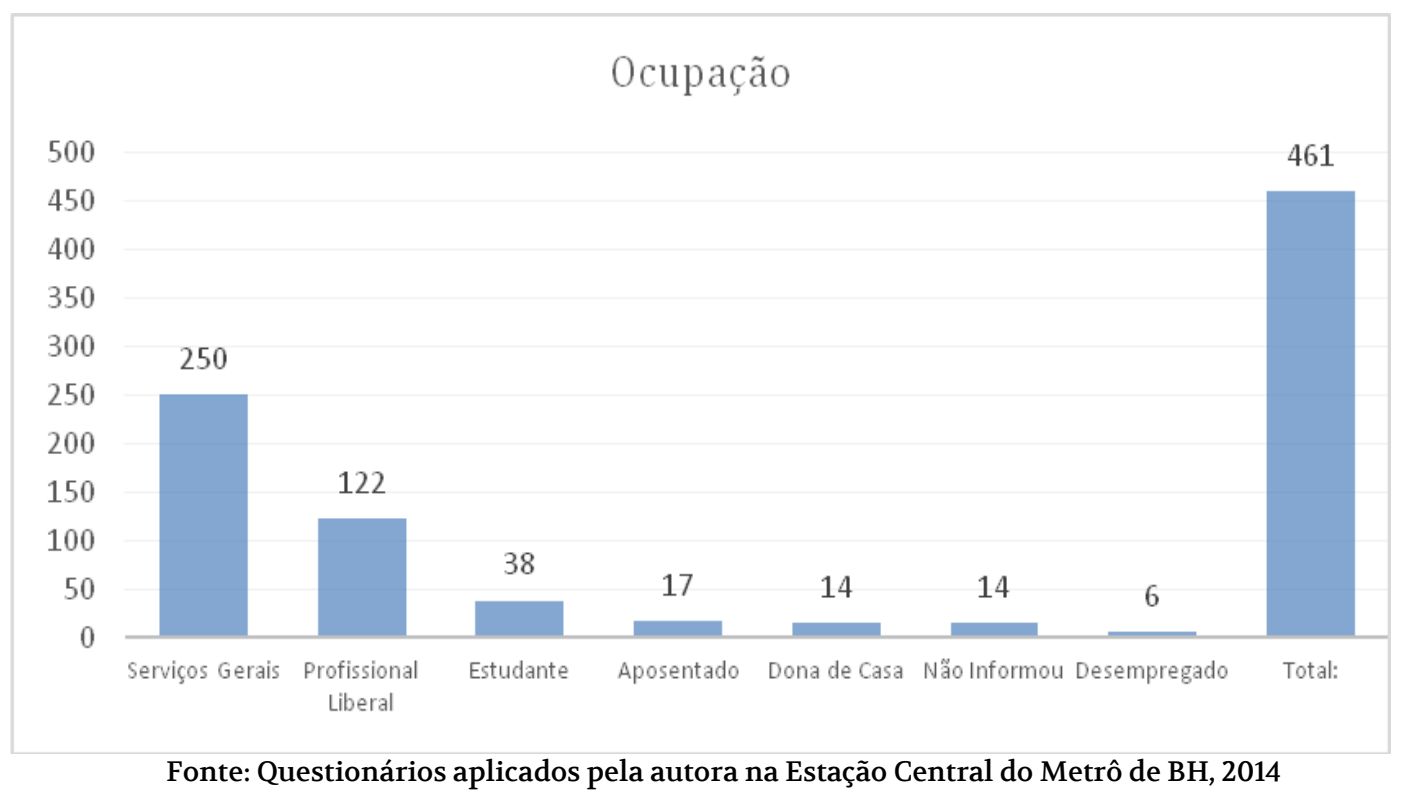

Dos que visitaram a instituição, procuramos identificar o aspecto de que eles mais gostaram. A coleção, como era de esperar, representou $46 \%$ da preferência do público, mas quase $10 \%$ apontaram a arquitetura do prédio como principal atrativo (gráfico 3). Um dado interessante a ser observado é que $20 \%$ das pessoas não se lembravam mais do que tinham visto no museu. Analisando o público de museus de arte em cinco países europeus, Pierre Bourdieu menciona que tais esquecimentos constituem um fenômeno comum entre aqueles que frequentam esse tipo de instituições, e não só as de arte, mas essa espécie de instituição de modo geral (BOURDIEU; DARBEL, 2007). 
Voltando aos números: uma pequena porcentagem (3\%) tinha frequentado o museu para participar de palestras/cursos ou exercer alguma atividade "extramuseológica", como é o caso dos fotógrafos de noivas. Nesses casos, as pessoas entrevistadas não se interessaram em conhecer a exposição. Para entender melhor esse público flutuante e eventual, conversamos com um fotógrafo que já tinha ido ao Museu pelo menos cinco vezes como profissional, contratado pelas noivas, e ele disse que nunca teve a "oportunidade" de conhecer a coleção lá exposta. Para ele, o que mais o impressionava (e interessava) era a "bela" edificação e as "tomadas fotográficas fantásticas" que o espaço arquitetônico possibilitava.

Gráfico 3- Preferência na visita realizada ao MAO

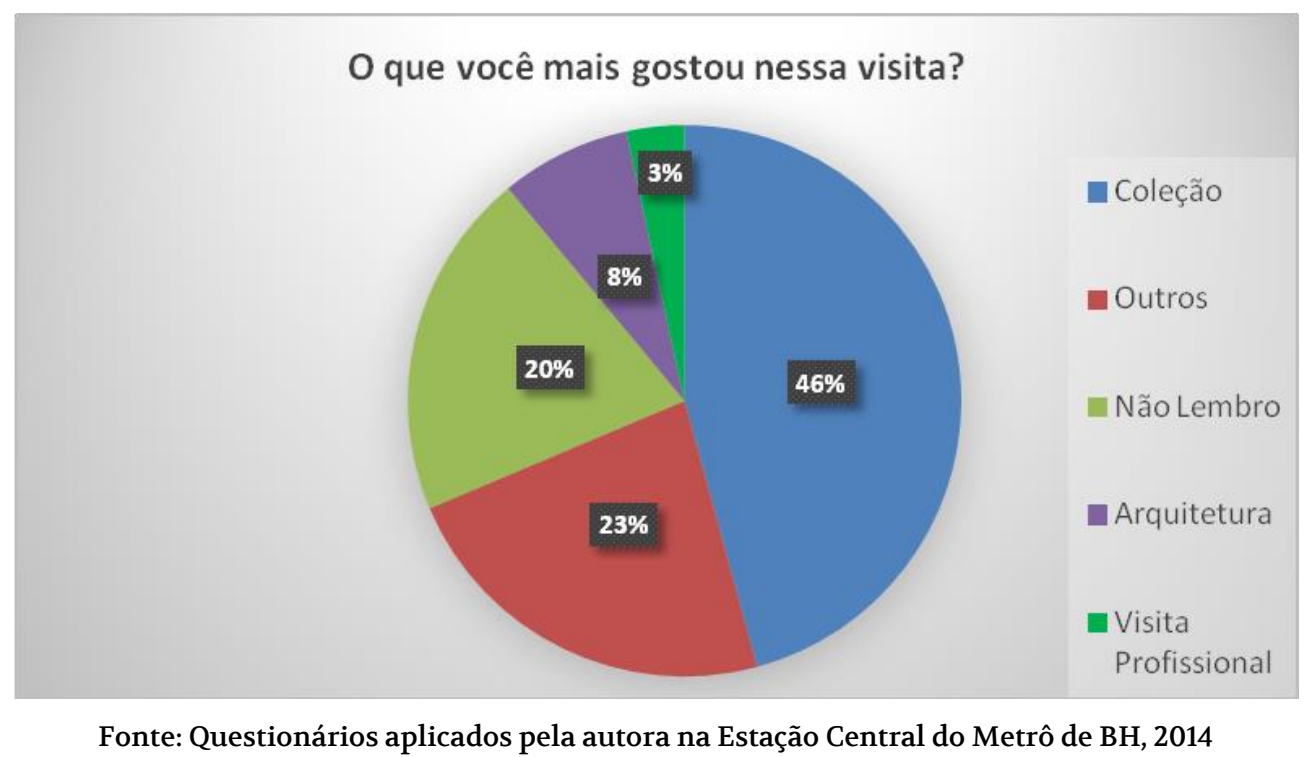

Queríamos compreender também por que as pessoas nunca quiseram visitar o museu, já que passam pela plataforma do Metrô diariamente. As respostas, dispostas no gráfico 4, indicam o seguinte resultado: $34 \%$ "não têm tempo"; $20 \%$ "não possuem interesse"; $11 \%$ não iam por "falta de oportunidade"; $28 \%$ "não sabiam que ali existia um museu" e $6 \%$ expuseram outros motivos. Podemos considerar a "falta de tempo, interesse e oportunidade", que somam mais de $80 \%$, como uma única variável; ou seja, há falta de interesse por esse tipo espaço cultural (gráfico 4). 
Gráfico 4- Motivo da não visita ao MAO

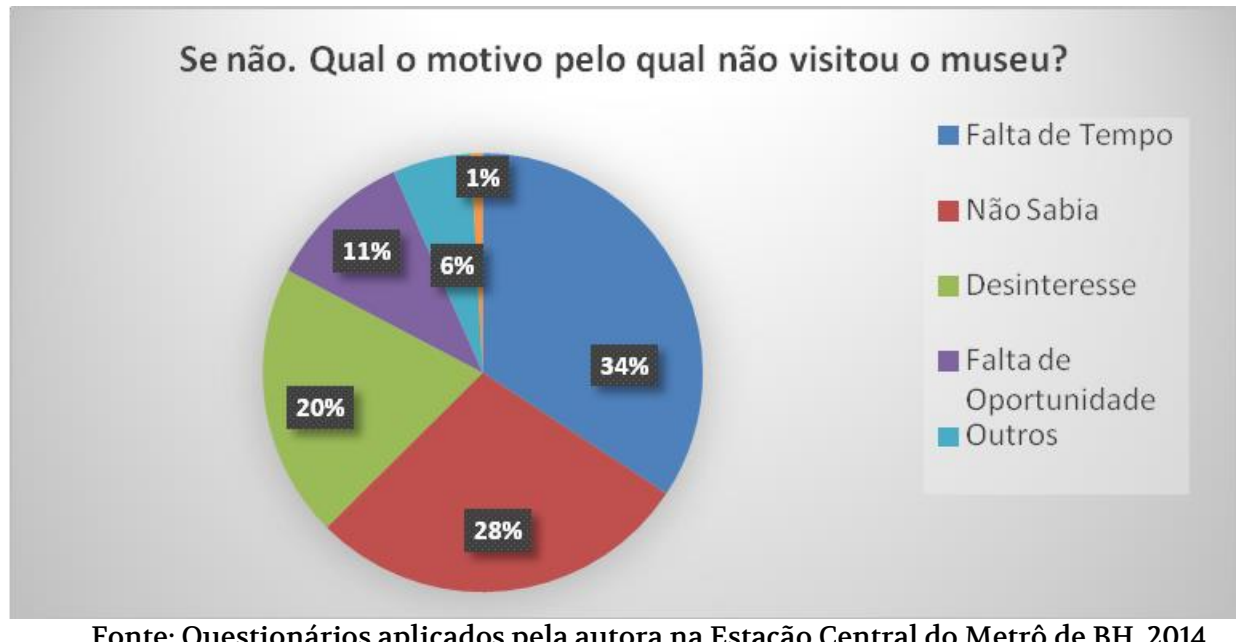

Entre as explicações possíveis para essa "falta de interesse" do público em relação aos museus, podemos aventar o fato de que no Brasil tais instituições não são, ainda, consideradas, espaços de lazer. Embora o Instituto Brasileiro de Museus (IBRAM) informe que, no início do século XXI, existam mais museus (3.025), no Brasil, do que salas de cinema (2.098) e teatros (1.229), eles ainda não são vistos como espaços de lazer e entretenimento. ${ }^{17}$

Dominique Poulot, ao analisar a realidade europeia, menciona que, a partir da década de 1960, os museus participaram gradualmente do consumo turístico e da economia de lazer:

[...] eles [os museus] têm a ver com a "cultura de massa", quando o número de seus visitantes está competindo com a clientela dos cinemas ou os espetáculos dos jogos de futebol. Assim, a Alemanha registra, anualmente, entre 90 a 95 milhões de visitantes por ano: à semelhança do que se passa em quase todos os países desenvolvidos, um terço da população frequenta regularmente os museus, outro terço entra raramente nesses espaços, enquanto o último terço nunca visitou um museu (POULOT, 2013, p. 11).

Enquanto, na Europa, 33\% da população são frequentadores assíduos dos museus, no Brasil apenas 3\% têm o hábito de visitá-los. Chama atenção que, nesse cenário museológico, as instituições dedicadas à história representem $67 \%$ do total de museus existentes no

\footnotetext{
${ }^{17}$ Dados retirados do site http://www.museus.gov.br do Instituto Brasileiro de Museus (IBRAM) e do Instituto Brasileiro de Geografia e Estatísticas (IBGE) em http://www.ibge.gov.br/.
} 
Brasil!18 A expectativa do IBRAM é que o resultado desse "censo museológico" sirva de referência para o planejamento de políticas públicas para o setor.

Como denota as propostas e as ideias do presente Dossiê, temos que repensar ininterruptamente os usos do patrimônio (para quê e para quem?), no qual as instituições estão mergulhadas, considerando, principalmente, que vivemos em um mundo plural, marcado por profundas desigualdades sociais e econômicas. Residiria aí o desinteresse do público usuário do metrô pelo museu aqui em destaque?

\section{Considerações finais}

Nota-se um interesse crescente da mídia pelas questões que envolvem a patrimonialização, a memória dos grupos sociais, os museus, as manifestações culturais e identitárias. Segundo Françoise Choay (2006), o patrimônio histórico, no qual os museus se incluem, tornou-se uma das palavras-chave da tribo midiática. Existe uma veneração do patrimônio histórico, de que a sociedade, muitas vezes, torna-se refém. A indústria cultural, por sua vez, confisca para si o direito de usufruir e reger os bens privados e públicos, direcionando gosto e consumo. Isso requer reflexões e questionamentos por parte dos historiadores e/ou pesquisadores preocupados, sobretudo, com a relação que o homem estabelece com o tempo, com o espaço e com os objetos neles inseridos.

Choay menciona, ainda, que o século XX assistiu a dois fenômenos socioculturais de grande envergadura. De um lado, pesquisadores (historiadores, arquitetos, conservacionistas, museólogos) que preconizam a necessidade (quase "esquizofrênica") de musealizar e ampliar ao máximo a noção de patrimônio. No caso do Brasil, os órgãos responsáveis por definir e legislar as questões culturais informam que o frevo, o samba de roda, a cidade de Ouro Preto, um terreiro de candomblé, o queijo mineiro, só para citar alguns exemplos, são considerados patrimônio cultural. Qualquer "coisa", ou melhor, "tudo", seguindo critérios e normas estabelecidas pelas instituições governamentais, pode e deve entrar na categoria "patrimônio cultural", numa espécie de "complexo de Noé" (CHOAY, 2006, p. 209).

Por outro lado, existe um discurso que invoca o direito dos artistas à criação. Para eles, é justo que, como seus predecessores, deixem suas balizas e sinais na urbanidade contemporânea. No desejo de transmitir seus legados, sustentam uma prática pautada pela

\footnotetext{
${ }^{18}$ Dados retirados http://www.museus.gov.br/.
} 
renovação e pela inovação como sinônimo de progresso e de civilização. Iconoclastas, não por natureza, mas por interesses, alinham as políticas patrimoniais a uma "dialética da destruição" (CHOAY, 2006, p. 16,17).

Observando essas questões por outro ângulo, Dominique Poulot lembra as centenas igrejas góticas destruídas em Paris, no século XVII e no começo do XVIII; para fins de "embelezamento", foram substituídas por edifícios barrocos ou "clássicos" (POULOT, 2009). Diferentemente dos europeus, no Brasil várias igrejas barrocas foram derrubadas, no início do século XX, em nome da reforma urbana e da consequente "higienização social" ocorridas na cidade do Rio de Janeiro (OLIVEIRA, 2003). Os exemplos são muitos e podem ser vistos em várias partes do mundo ocidental.

O grande paradoxo desse discurso conservacionista e as práticas ligadas ao patrimônio têm como referência primeira o século XVIII, mais precisamente o movimento/pensamento iluminista. Segundo Hartog (2006), é no século XVIII que a ciência moderna se configura; o homem não só volta os olhos à preservação dos monumentos do Passado, mas também é a partir daí que os museus buscam classificar, organizar e divulgar seus acervos como forma de preservar o conhecimento e os feitos científicos da humanidade. $O$ autor lembra que, até o Setecentos, o homem estabelecia uma relação de tempo em que o passado regulava a referência do presente e do futuro - História Magistra.

O Iluminismo não só rompe com essa ideia, mas também propõe, em nome do progresso e da razão, uma nova forma de se relacionar com o tempo. Chamado pelos teóricos de Regime Moderno de historicidade, a história seria pensada e escrita teleologicamente, do ponto de vista do futuro. Diferente da História Magistra, que durou séculos, essa nova percepção do tempo sofreria, segundo os estudiosos, um novo, e definitivo, revés na década de 1980. Mais especificamente o ano de 1989 vai romper com essa lógica e instaurar uma nova ordem, uma nova analogia com o tempo, denominada por Hartog de Presentismo.

Nota-se, com isso, que "se vive entre a amnésia e a vontade de nada esquecer". (HARTOG, 2006). Estariam os museus do século XXI, em especial o Museu de Artes e Ofícios, mergulhado nessa problemática? A preocupação com a memória, traduzida por meio dos objetos congelados na exposição de longa duração, não seria um sintoma apontado por esse e outros estudiosos? ${ }^{19}$

Dentro do diálogo proposto no início deste artigo vejamos essas mesmas questões pela lente do antropólogo Nestor Canclini (1994). O estudioso argentino ressalta que, nos debates sobre o patrimônio histórico, costuma-se ver como "inimigos dos atuais processos de mudança o desenvolvimento urbano, a mercantilização, a indústria cultural e o turismo".

${ }^{19}$ Além de François Hartog, adotamos como parâmetro de análise os estudiosos Reinhart Koselleck e Pierre Nora devidamente citados na bibliografia final. 
Para ele, essas "ameaças fazem parte dos contextos que não só devemos aceitar por serem as condições em que hoje os bens históricos existem, mas também porque contribuem para repensar o que devemos entender por patrimônio e por identidade nacional" (CANCLINI, 1994, p. 95).

Assim, como conciliar a função conservacionista do MAO com as múltiplas funções da Praça da Estação, a qual é utilizada também para eventos culturais (shows de bandas, feiras etc.), manifestações sociais e políticas (comícios, greves e protestos populares, como os de junho de 2013)? Como ajustar um espaço de conservação com o barulho (muitas vezes excessivo) das caixas de som, que fazem estremecer as paredes dos museus? Como harmonizar o público visitante com os transeuntes? Como o Museu pode e deve conviver com seus vizinhos, com os moradores de rua e com os usuários de drogas na região? Como o Museu deve lidar com o fato de que $20 \%$ do público do metrô ignoram que ali, bem pertinho deles, existe um espaço de memória relacionado ao mundo do trabalho e do trabalhador? Como usufruir aquele "belo" e "importante" edifício, sem afastar o trabalhador, acostumado a ambientes mais simples - "Parece um palácio, deve ser caro entrar lá"?

Para tantas questões, não temos uma resposta. No entanto, essas indagações sugerem a necessidade de ser elaborada uma agenda que tenha como ponto de partida exatamente esse conjunto de problemas arrolado e que exige uma reflexão profunda e permanente. As "soluções" não virão facilmente, porque delas não dependem só os museus, mas as políticas públicas que envolvem a cidade e as múltiplas demandas de quem a habita. Por esse motivo, Canclini alerta: "não basta que as escolas e os museus estejam abertos a todos, que sejam gratuitos e promovam em (todos os setores) sua ação difusora; à medida que descemos na escala econômica e educacional diminui a capacidade de apropriação do capital cultural transmitido por essas instituições" (CANCLINI, 1994, p. 96, grifos nossos).

Há quase meio século, em 1966, quando Pierre Bourdieu e Alain Darbel escreveram "O amor pela arte: os museus de arte na Europa e seu público” já questionavam, também, porque apenas parte da sociedade conseguia (usu)fruir adequadamente as obras de arte. Investigavam e estavam interessados, ainda, em desvendar e caracterizar quem eram aquelas pessoas que frequentavam tais instituições. Suas conclusões apontaram, entre muitas outras questões, que a frequência aos museus de arte, por exemplo, aumentava consideravelmente à medida que crescia o nível de instrução (BOURDIEU; DARBEL, 2007).

Importa dizer que, no limiar do século XXI (quando o MAO foi criado), as instituições museais já tinham adquirido um perfil socioeconômico mais popular e transparente, daí a preocupação com os projetos e as ações sociais. E, como se pôde perceber com base nos números indicados pelo "censo museológico", o museu apresenta-se como uma das maiores unidades de cultura em nossa época, numericamente superior aos cinemas e teatros, só para ficar nessas duas "dimensões" culturais. 
Enfim, os múltiplos empregos, funções e papéis que os museus precisam desempenhar na atualidade - colecionar, preservar, estudar, interpretar e comunicar - fazem deles poderosos veículos sociais, particularmente no que se refere a estratégias para o desenvolvimento humano. Ademais, é importante destacar que o final do século XX e o início do XXI há por parte da gestão dessas instituições uma preocupação (às vezes excessiva) com o público. Nesse sentido, o Museu enfocado aqui tenta administrar essa difícil operação, buscando equalizar interesse público para além da (nem sempre) simples função preservacionista e da comunicação de sua vasta e complexa coleção.

Embora ainda não tenha sido possível averiguar integralmente os resultados do mencionado projeto, os problemas elencados nortearam o trabalho ora apresentado. Esperase, por fim, que as informações analisadas possam suscitar outras tantas que possivelmente não foram aqui aventadas.

\section{Bibliografia}

ADUM, Sonia. M. S. L. Historiografia Norte Paranaense: alguns apontamentos. In: ALEGRO, Regina Célia. (Org.). Temas e Questões para o Ensino de História do Paraná. Londrina: EDUEL, 2008. p. 3-26.

ALVES, Rafael da Silva. Lendo o Museu. Relações entre a expografia e a historiografia no Museu da Inconfidência - Ouro Preto/MG. 2013. Dissertação (Mestrado) - Faculdade de Filosofia e Ciências Humanas, Universidade Federal de Minas Gerais, 2013.

BLOCH, Marc. Apologia da história ou O oficio de historiador. Trad. André Telles. Rio de Janeiro: Zahar, 2002.

BOURDIEU, Pierre; DARBEL, Alain. $O$ amor pela arte: os museus de arte na Europa e seu público. 2. ed. Trad. Guilherme João de Freitas. São Paulo: Editora da Universidade de São Paulo; Porto Alegre: Zouk, 2007.

BREFE, Ana Cláudia Fonseca. O Museu Paulista Affonso de Taunay e a memória nacional. 19171945. São Paulo: Ed. UNESP, 2005.

CANCLINI, Nestor García. O patrimônio cultural e a construção imaginária do Nacional. Trad. Maurício Santana Dias. Revista do Patrimônio Histórico e Artístico Nacional. Rio de Janeiro: Arquivo Nacional, v. 23, p. 94-115, 1994.

CHOAY, Françoise. A alegoria do patrimônio. Tradução de Luciano Vieira Machado. São Paulo: Estação Liberdade: UNESP, 2006.

GUINZBURG, Carlo. O queijo e os vermes. O cotidiano e as ideias de um moleiro perseguido pela Inquisição. Trad. Maria Betânia Amoroso. São Paulo: Companhia das Letras, 1987. 
HARTOG, François. Tempo e Patrimônio. Tradução de José Carlos Reis. Varia História. Belo Horizonte: v. 22, n. 36, p.261-273, jul/dez. 2006.

JULIÃO, Letícia. Apontamentos sobre a história do museu. Caderno de diretrizes museológicas. Brasília: Ministério da Cultura, Instituto do Patrimônio Histórico e Artístico Nacional, 2006.

KOSELLECK, Reinhart. Futuro passado: contribuição à semântica dos tempos históricos. Tradução de Wilma Patrícia Maas e Carlos Almeida Pereira. Rio de Janeiro: Contraponto, PUC-Rio, 2006.

LEME, Edson José Holtz. O teatro da memória: o Museu Histórico de Londrina - 1959-2000. Tese (Doutorado) - UNESP, Assis, 2013.

LIMA, Solange Ferraz de; CARVALHO, Vânia Carneiro de. Cultura material e coleção em um museu de história: as formas espontâneas de transferência do provado. In: FIGUEIREDO, Betânia Gonçalves (Org.). Museus: Dos gabinetes de Curiosidades à Museologia Moderna. Belo Horizonte: Argvmentvm; Brasília: CNPq, 2005.

MENESES, Ulpiano Toledo Bezerra de. Do Teatro da memória ao Laboratório da História: a exposição museológica e o conhecimento histórico. Anais do Museu Paulista: História e Cultura Material, São Paulo, v. 2, n. 1, p. 9-42, jan/dez. 1994.

MILLER, Daniel. Trecos, troços e coisas - estudos antropologicos sobre a cultura material. Rio de Janeiro: Zahar, 2013.

MUSEU DE ARTES E OFÍCIOS. Catálogo. Instituto Cultural Flávio Gutierrez. Presidente do Instituto, Angela Gutierrez. Programa Educativo Helena Mourão Loureiro. 2013. MUSEU HISTÓRICO ABÍLIO BARRETO. Álbum Museu Histórico Abílio Barreto. 5. ed. Belo Horizonte, 2003.

NORA, Pierre. Entre memória e história: a problemática dos lugares. Tradução de Yara Aun Khoury. Projeto História, São Paulo, n. 3, dez. 1993.

OLIVEIRA, Myriam Andrade Ribeiro de. O rococó religioso no Brasil e seus antecedentes europeus. São Paulo: Cosac \& Naify, 2003.

POULOT, Dominique. História do Patrimônio no Ocidente, séculos XVIII-XXI. Do monumento aos valores. Tradução de Guilherme João de Freitas Teixeira. São Paulo: Estação Liberdade, 2009.

POULOT, Dominique. Museu e Museologia. Tradução de Guilherme João de Freitas Teixeira. Belo Horizonte: Autêntica Editora, 2013.

POSSAS, Helga Cristina Gonçalves. Classificar e ordenar: os gabinetes de curiosidades e a história natural. In: FIGUEIREDO, Betânia Gonçalves (Org.). Museus: Dos gabinetes de Curiosidades à Museologia Moderna. Belo Horizonte: Argvmentvm; Brasília: CNPq, 2005.

SANTOS, Miriam Sepúlveda dos Santos. A escrita do passado em museus históricos. Rio de Janeiro: Garamond, Minc, IPHAN, DEMU, 2006. 


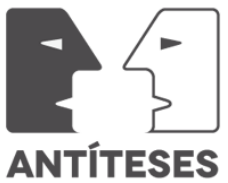

SEMINÁRIO CULTURA E EDUCAÇÃO: parceria que faz história, 2006, Belo Horizonte. Anais... Belo Horizonte: Mazza Edições, Instituto Cultural Flávio Gutierrez/MAO, 2006. 